\title{
Dietary acid load in a group of kidney transplantation candidates
}

\author{
Carga ácida da dieta em um grupo de candidatos ao transplante renal \\ Carga ácida de la dieta en un grupo de candidatos a transplante de riñón
}

Received: 04/29/2021 | Reviewed: 05/05/2021 | Accept: 05/09/2021 | Published: 05/22/2021

Lívia Torres Medeiros

ORCID: https://orcid.org/0000-0001-7709-9377 Faculdade Inspirar, Brasil

E-mail: livia.torresm@gmail.com

Andressa Eslayne Caldas Sales

ORCID: https://orcid.org/0000-0002-7266-4741 Universidade Federal do Ceará, Brasil E-mail: andressa_slayne@hotmail.com

Francisca Isabelle da Silva e Sousa ORCID: https://orcid.org/0000-0001-6226-3381 Universidade Federal do Ceará, Brasil E-mail: isabelle_sousa@outlook.com

Tyciane Maria Vieira Moreira

ORCID: https://orcid.org/0000-0001-8312-1534 Universidade Federal do Ceará, Brasil

E-mail: tycianevieira@ hotmail.com

Ana Clara Vital Batista

ORCID: https://orcid.org/0000-0001-7471-1663 Universidade Federal da Bahia, Brasil E-mail: ana_clara_vital@hotmail.com

Ribanna Aparecida Marques Braga

ORCID: https://orcid.org/0000-0003-2122-5658

Universidade Estadual do Ceará, Brasil

E-mail: ribanna.marques@ aluno.uece.br

Lorena Taúsz Tavares Ramos

ORCID: https://orcid.org/0000-0002-2364-5499

Universidade Estadual do Ceará, Brasil

E-mail: lo.tausz@gmail.com

Fábia Karine de Moura Lopes

ORCID: https://orcid.org/0000-0001-5964-858X Universidade Estadual do Ceará, Brasil

E-mail: karinemouranutricionista@gmail.com

Ana Filomena Camacho Santos Daltro

ORCID: https://orcid.org/0000-0003-2196-9198

Universidade de Fortaleza, Brasil

E-mail: afcsd@hotmail.com

\begin{abstract}
Objective: The objective of the study was to estimate and analyze the Potential Renal Acid Load (PRAL) of the diet in patients maintenance hemodialysis who are candidates for transplantation. Methodology: A cross-sectional study was conducted. The sample was separated in terciles of the PRAL. For the association between the PRAL and the independent variables, non-adjusted multinomial logistic regression and adjusted by potential confounders were implemented. It was assumed a $\mathrm{p}<0,05$ for statistical significance. Results: It was noticed that protein (g), the protein $/ \mathrm{kg}$ of weight $(\mathrm{g} / \mathrm{kg})$, \% of animal and vegetal protein, the phosphorus $(\mathrm{mg})$, the lipid $(\mathrm{g})$, and the carbohydrate $(\mathrm{g})$ showed differences between the terciles $(\mathrm{p}<0,05)$. In regression, the greatest consumption of protein $(\mathrm{g})$, protein $\mathrm{g} / \mathrm{kg}$ of weight $(\mathrm{g} / \mathrm{kg}), \%$ of animal protein and lipid $(\mathrm{g})$ was associated with the tercile 3 to tercile 1 , whereas the greatest consumption of carbohydrate and \% vegetal protein showed a protective effect. Conclusion: The results show an association between the PRAL and the protein consumption with the difference between the sources. It was not found an association between PRAL and the variables of nutritional status.
\end{abstract}

Keywords: Kidney transplantation; Renal dialysis; Animal proteins, Dietary; Dietary plant proteins.

\section{Resumo}

Objetivo: O objetivo do estudo foi estimar e analisar o Potential Renal Acid Load (PRAL) da dieta de pacientes renais em hemodiálise candidatos ao transplante. Metodologia: Foi realizado um estudo transversal. A amostra foi separada em tercis do PRAL. Para a associação entre o PRAL e as variáveis independentes, foi implementada regressão logística multinomial não ajustada e ajustada por potenciais confundidores. Assumiu-se $p<0,05$ para significância 
estatística. Resultados: Percebeu-se que a proteína (g), a proteína / $\mathrm{kg}$ de peso $(\mathrm{g} / \mathrm{kg}), \%$ de proteína animal e vegetal, o fósforo $(\mathrm{mg})$, o lipídeo $(\mathrm{g})$ e o carboidrato $(\mathrm{g})$ apresentaram diferenças entre os tercis (p <0,05). Na regressão, o maior consumo de proteína $(\mathrm{g})$, proteína $\mathrm{g} / \mathrm{kg}$ de peso $(\mathrm{g} / \mathrm{kg}$ ),\% de proteína animal e lipídio $(\mathrm{g}$ ) foi associado do tercil 3 ao tercil 1, enquanto o maior consumo de carboidrato e \% proteína vegetal apresentou efeito protetor. Conclusão: Os resultados mostram uma associação entre o PRAL e o consumo de proteína com a diferença entre as fontes. Não foi encontrada associação entre PRAL e as variáveis do estado nutricional.

Palavras-chave: Transplante de rim; Diálise renal; Proteínas animais da dieta; Proteínas vegetais dietéticas.

\section{Resumen}

Objetivo: El objetivo del estudio fue estimar y analizar el Potential Renal Acid Load (PRAL) de la dieta de pacientes renales en hemodiálisis candidatos a trasplante. Metodología: se realizó un estudio transversal. La muestra se separó en terciles del PRAL. Para la asociación entre el PRAL y las variables independientes, se implementó una regresión logística multinomial no ajustada y se ajustó por posibles factores de confusión. Se asumió una p <0,05 para significancia estadística. Resultados: Se notó que proteína $(\mathrm{g})$, proteína / $\mathrm{kg}$ de peso $(\mathrm{g} / \mathrm{kg}) \%$ de proteína animal y vegetal, fósforo $(\mathrm{mg})$, lípidos $(\mathrm{g})$ y carbohidratos $(\mathrm{g})$ mostraron diferencias entre terciles ( $\mathrm{p}<0,05)$. En la regresión, el mayor consumo de proteína $(\mathrm{g})$, proteína $\mathrm{g} / \mathrm{kg}$ de peso $(\mathrm{g} / \mathrm{kg}), \%$ de proteína animal y lípidos $(\mathrm{g})$ se asoció del tercil 3 al tercil 1, mientras que el mayor consumo de carbohidratos y \% de proteína vegetal mostró un efecto protector. Conclusión: Los resultados muestran una asociación entre PRAL y el consumo de proteínas con la diferencia entre fuentes. No se encontró asociación entre PRAL y variables del estado nutricional.

Palabras clave: Trasplante de riñón; Diálisis renal; Proteínas dietéticas animales; Proteínas dietéticas vegetales.

\section{Introduction}

The Chronic Kidney Disease (CKD) is characterized by the slow and gradual loss of renal function. In general, it is diagnosed by the reduction of the Glomerular Filtration Rate (GFR) to amounts below $60 \mathrm{ml} / \mathrm{min} / 1,73 \mathrm{~m}^{2}$ or the detection of the presence of signs of renal damage for a period of time equal or superior to 3 months. This pathology derives from a series of clinical conditions that progress with the worsening of renal function, such as diabetes and arterial hypertension. Among the possibilities of treatment are the conservative therapy, dialysis and renal transplant (Webster et al., 2017).

The CKD evolves with various metabolic complications as there is reduction of renal function, among them the metabolic acidosis, that encompasses a process in which there is an accumulation of hydrogen ions and/or loss of bicarbonate through the urine by specific physio-pathologic mechanisms (Harambat et al., 2017). This complication of the disease, when not corrected, may have damaging effects over bone health and protein metabolism, impairing protein synthesis, increasing the oxidation of amino acids and reducing the synthesis of albumin. These factors lead to the reduction of mass and muscular strength, being the correction of the metabolic acidosis associated with the improvement of the nutritional status of this population (Sajgure et al., 2017).

Furthermore, patients with CKD in terminal state tend to have a systemic chronic inflammatory state of multifactorial etiology, including metabolic acidosis, which elevates the losses of protein and energy reserves, condition known as ProteinEnergy Wasting Syndrome (PEWS) (Akchurin \& Kaskel, 2015). The compromising of the nutritional state is related to worse prognostics and post-transplant complications, such as an increase in the incidence of infections, metabolic complications, high cardio-vascular risk and lower life span of the renal graft (Chung et al., 2015).

The acid-base state is affected by the diet, since animal proteins elevate the endogenous production of hydrogen, whereas vegetal proteins increase the production of alkalis (Goraya \& Wesson, 2017). From this relation the algorithm of Potential Renal Acid Load (PRAL) was created. It is capable of estimating the acids and bases forming potential of foods and diets, in which more negative values are related with a greater ingestion of alkalis (Raphael, 2019).

A review implemented by Osuna-Padilla et.al. (2019), shows that more acid diets determined by PRAL, Net Acid Production (NEAP) and urinary pH may influence the acid-base balance and promote low-grade metabolic acidosis, leading to metabolic abnormalities such as osteoporosis, nephrolithiasis, CKD, resistance to insulin action, possibly culminating in diabetes mellitus type 2 and non-alcoholic hepatopathy; loss of muscular mass, increase of arterial pressure and higher 
cardiovascular risk.

Considering the influence of the diet in the endogenic production of acids and its impact over the nutritional status on patients with CKD, it is of outmost importance to investigate its association with consumption in order to foment alternatives to clinical practice, such as the creation of clinical protocols for dealing with low-grade metabolic acidosis through diet, avoiding unnecessary restrictions of vegetables and maintaining a healthy feeding standard for the maintenance of the health of the patients after undergoing transplant and contributing with better post-transplant outcomes. Furthermore, the scientific literature is short on studies that evaluate the theme. Since studies that involve this theme on patients in waiting lists for transplant are scarce in the literature. Therefore, the objective of the study was to estimate and analyze the Potential Renal Acid Load (PRAL) of the diet in patients maintenance hemodialysis who are candidates for transplantation.

\section{Methodology}

\section{Outlining of the study, population, recruitment and ethical considerations.}

This is an observational, prospective, cross-sectional study, descriptive, with analytical outlining and quantitative approach. Realized with patients in the renal transplant ambulatory of a University Hospital in the Northeast of Brazil during a nutritional consultation. The sampling occurred in the period of July 2018 to May 2019.

The sample was non-probabilistic by convenience, being included individuals of both genders adult $(\geq 19$ years old $\mathrm{e}<$ 60 years old) and elderly ( $\geq 60$ years old) on hemodialysis and that were enlisted in a renal transplant waiting list. Patients who were in conservative treatment and in peritoneal dialysis, transplant donors, those who were being prepared to be enlisted in the waiting list, as well as those who were unable to cooperate or perform any anthropometric technique were excluded.

The recruitment of participants was conducted by the local nutritionists' team trained for the execution of anthropometric and functional measures and collection of dietary history of renal patients. The team was guided to conduct direct analysis of the patients' promptuaries of the patients waiting for medical care, in order to check whether these patients fulfilled the criteria for inclusion in the study, after that the patients were invited to participate in the study and all the information about the objective of the study, the volunteer basis of their participation, duration and content of the session of data collection was provided to them.

The interview and data collection were done after the signature of the Informed Consent Form (ICF). This study was analysed by the local ethics and research according to the resolution of the national health council 466/12 (Ministério da Saúde \& Conselho Nacional de Saúde, 2012).

\section{Sociodemographic, clinical and physical activity data}

Aiming at better describing the population studied, data was collected during the nutritional interview by applying a semi-structured pre-defined form, as well as consultation to their promptuary. Sociodemographic data was collected (age, gender, income, country of birth, level of education, history of elitism and smoking habits), level of physical activity and clinical data as well (etiology of the CKD, time of diagnosis, time of hemodialysis and biochemical exams: urea (mg/dL), creatinine $(\mathrm{mg} / \mathrm{dL})$, albumin $(\mathrm{g} / \mathrm{L})$, potassium $(\mathrm{mEq} / \mathrm{L})$ and alkaline reserve $(\mathrm{mEq} / \mathrm{L}))$.

The biochemical exams were conducted by the transplantation center itself and consulted in the promptuary. From the serum creatinine was realized the calculation of an estimative of the Glomerular Filtration Rate (GFR) by the equation of Chronic Kidney Disease Epidemiology Collaboration (CKD-EPI) (Stevens et.al., 2010).

Intending to categorize the level of physical activity, the participants were classified as active when they exercised for a minimum period of 150 minutes a week in a moderate intensity or at least 75 minutes in a vigorous intensity (World Health Organization, 2010). 


\section{Anthropometric and functional data}

For the evaluation of the nutritional status of the subjects, the following anthropometric data were used: post-dialysis weight $(\mathrm{Kg})$ and height $(\mathrm{m})$. For functional evaluation Hand Grip Strength was used - HGS (Kg). The patients were enquired about their post-dialysis weight of their last hemodialysis session. The height was determined through the use of a stadiometer with a precision of $0,1 \mathrm{~cm}$ attached to a platform digital scale (Filizola ${ }^{\circledR}$, Brazil), for that the patients were requested to step onto the scale with their back turned to it, so that their posterior part of the body would be touch the equipment, barefoot, without hair ornaments, in anatomic position and with their head positioned in the "Frankfurt plane" (Brasil, 2011). The Body Mass Index (BMI) was calculated from the ratio between post-dialysis weight and height [BMI = Post-dialysis weight $(\mathrm{Kg}) /$ height $\left.^{2}(\mathrm{~m})\right]$.

The patients that were classified as undernourished presented BMI $<23 \mathrm{Kg} / \mathrm{m}^{2}$, eutrophic with $\mathrm{BMI} \geq 23 \mathrm{Kg} / \mathrm{m}^{2}$, as recommended by the International Society in Renal Nutrition and Metabolism (Fouque et.al., 2008) and overweight above $30 \mathrm{Kg} / \mathrm{m}^{2}$, according to the World Health Organization (1997).

The HGS was measured according to the protocol of the American Society of Hand Therapists (ASHT) (Fess, 1992). The patients were kept seated in a way that their feet would touch the ground, with the arm opposite to the Arteriovenous Fistula (AVF) beside the thorax and flexed elbow in a $90^{\circ}$ position with the forearm, the patient were asked to press the handheld dynamometer (Lafayette $\AA$, Brazil) with maximum force, this measure was taken in triplicate, attaining to 1 minute of interval between measurements, in which the highest value was considered. The individuals were classified with low muscular strength with HGS $<27 \mathrm{Kg}$ for men and $<16 \mathrm{Kg}$ for women, as proposed by the European Working Group on Sarcopenia in Older People 2 (EWGSOP2) (Cruz-Jentoft, 2019).

\section{Dietary data and PRAL}

The dietary history was collected from two 24-hour dietary recalls (Rc24h) because it is a more recent and of faster application food intake measurement. They were conducted for two days over the telephone: one day of the weekend and another of hemodialysis. For the analysis of the dietary recalls the software Dietwin® Profissional 2011 of dietary evaluation was used, in order to obtain the average of two days in relation to the consumption of total calories (kcal), Carbohydrates ( $\mathrm{g}$ ), Lipids (g), Animal Protein (\%), Vegetal Protein (\%), Proteins/kg of weight (g/Kg), Proteins (g), Phosphorus (mg), Potassium (mg), Calcium (mg) and Magnesium (mg).

All the nutrients intakes were adjusted for total energy intake according to the Willet's residual method (Willett, 1997). The amount of proteins, phosphorus, potassium, calcium and magnesium were subsequently used to determine the Potential Renal Acid Load (PRAL) through the algorithm created by Remer and Manz (1995), where:

\footnotetext{
PRAL $(\mathbf{m E q} / \mathbf{d})=0,4888 \times$ protein $(\mathrm{g} /$ day $)+0,0366 \times$ phosphorus $(\mathrm{mg} /$ day $)-0,0205 \times$ potassium $(\mathrm{mg} /$ day $)-0,0125$ $\mathrm{x}$ calcium (mg/day) - 0,0263 x magnesium (mg/day).
}

Negative or near zero values of PRAL were considered more alkaline diets, on the other hand, more positive values are responsible for the increase on the production of acids, characterizing a more acidic diet (Remer \& Manz, 1995).

\section{Statistical analysis}

Exploratory analysis was conducted through tables and graphs. The dependent variable was the PRAL and the independent variables related to food intake were classified in dietary data; the biochemical exams, estimate of GFR and time of hemodialysis were classified as clinical data, and lastly the BMI and HGS were classified as nutritional evaluation. Shapirowilk statistical tests were conducted to verify normality and Levene tests to check homogeneity. 
The numerical variables were expressed in average and standard-deviation (SD) of the average, and the categorical variables in frequency and percentage. For statistical analysis of the data the software Statistical Package for the Social Sciences - SPSS 22.0 was used and the graphics were developed using the GraphPad Prism version 8.0. For the categorical variables the Pearson Chi-Squared and the Fisher Exact Tests were conducted. For better characterization of the sample, it was distributed in terciles of PRAL. For comparison of average variation in the terciles, ANOVA one-way e Kruskal-Wallis statistical tests were used. For association between the Potential Renal Acid Load and the independent variables, non-adjusted multinomial logistic regression and adjusted by gender, age, time of diagnosis and time of hemodialysis were implemented. Regression was conducted respecting the suppositions of non-multicolinearity and quality testing of the adjustment by the Hosmer and Lemeshow test. A sample calculation was performed posteriori using the G*Power software 3.1.9.7, the effect size $(d=0.35)$, significance level $(0.05)$ and power of the study $(0,99)$ were observed. A $p<0,05$ for statistical significance was accepted.

\section{Results}

The sample was composed of 98 patients, being 53,1\% ( $\mathrm{n}=52)$ of female gender, with an average age of 44,80 $(\mathrm{SD}=12,77)$ years old, ranging from 19 to 74 years old. In relation to life style, the majority of the studied population was sedentary $(90,8 \%, \mathrm{n}=89)$ and did not show history of smoking habits $(66,3 \%, \mathrm{n}=65)$. Considering the genders, it is observed only a significant statistical difference between the elitism $(\mathrm{p}<0,01)$, in which the male gender presents a superior history $(78,3 \%)$. Other variables of characterization of the sample are present in Table 1. 
Table 1 - Sociodemographic characteristics and life style of patients committed with CKD in hemodialysis listed for transplant in a university hospital in the northeast of Brazil. (2019).

\begin{tabular}{|c|c|c|c|c|c|c|c|}
\hline \multirow{2}{*}{ Characteristics } & \multicolumn{2}{|c|}{ Total } & \multicolumn{2}{|c|}{ Male } & \multicolumn{2}{|c|}{ Female } & \multirow[b]{2}{*}{$p$} \\
\hline & $\mathbf{n}$ & $\%$ & $\mathbf{n}$ & $\%$ & $\mathbf{n}$ & $\%$ & \\
\hline \multicolumn{8}{|l|}{ Age range } \\
\hline$\leq 60$ & 88 & 89,8 & 40 & 87,0 & 48 & 92,3 & \multirow{2}{*}{$0,508^{£}$} \\
\hline$>60$ & 10 & 10,2 & 6 & 13,0 & 4 & 7,7 & \\
\hline \multicolumn{8}{|l|}{ Place of birth } \\
\hline Northeast & 88 & 89,8 & 39 & 84,8 & 49 & 94,2 & \multirow{2}{*}{$0,182^{£}$} \\
\hline Other regions & 10 & 10,2 & 7 & 15,2 & 3 & 5,8 & \\
\hline \multicolumn{8}{|l|}{ Income } \\
\hline$\leq 3$ wages & 84 & 85,7 & 40 & 87,0 & 44 & 84,6 & \multirow{2}{*}{$0,781^{\ddagger}$} \\
\hline$>3$ wages & 14 & 14,3 & 6 & 13,0 & 8 & 15,4 & \\
\hline \multicolumn{8}{|l|}{ Education } \\
\hline Illiterate/middle school & 44 & 44,9 & 21 & 47,7 & 23 & 52,3 & \multirow{3}{*}{$0,398^{\ddagger}$} \\
\hline High school & 36 & 36,7 & 19 & 52,8 & 17 & 47,2 & \\
\hline Undergraduate & 18 & 18,4 & 6 & 33,3 & 12 & 66,7 & \\
\hline \multicolumn{8}{|l|}{ History of alcohol consumption } \\
\hline No & 46 & 46,9 & 10 & 21,7 & 36 & 69,2 & \multirow{2}{*}{$<0,01^{\ddagger}$} \\
\hline Has consumed alcohol & 52 & 53,1 & 36 & 78,3 & 16 & 30,8 & \\
\hline \multicolumn{8}{|l|}{ History of Smoking } \\
\hline No & 65 & 66,3 & 27 & 58,7 & 38 & 73,1 & \multirow{3}{*}{$0,253^{\ddagger}$} \\
\hline Has smoked & 33 & 33,7 & 19 & 41,3 & 14 & 26,9 & \\
\hline \multicolumn{7}{|l|}{ Physical activity } & \\
\hline Sedentary & 89 & 90,8 & 41 & 89,1 & 48 & 92,3 & \multirow{2}{*}{$0,730^{£}$} \\
\hline Active & 9 & 9,2 & 5 & 10,9 & 4 & 7,7 & \\
\hline
\end{tabular}

$\mathrm{n}$ - frequency; ${ }^{\mathfrak{f}}$ Fisher exact test; ${ }^{\star}$ Pearson chi-square test; $\mathrm{p}$ value $-\mathrm{p}<0,05$. Source: Authors.

There was statistical difference between genders for creatinine, albumin and HGS $(\mathrm{p}<0,05)$, in which the male gender presented significantly higher averages. There was not a perceivable difference between genders in relation to dietary data, other clinical data and BMI, as described in Table 2. 
Table 2 - Comparison of dietary and clinical data and nutritional evaluation according to the genders of patients committed with CKD undergoing hemodialysis listed for transplant in a university hospital in the northeast of Brazil. (2019)

\begin{tabular}{|c|c|c|c|c|c|c|c|}
\hline \multirow{2}{*}{ Variables } & \multicolumn{2}{|c|}{ Total } & \multicolumn{2}{|c|}{ Male } & \multicolumn{2}{|c|}{ Female } & \multirow[b]{2}{*}{$p$} \\
\hline & Average & SD & Average & SD & Average & SD & \\
\hline \multicolumn{8}{|l|}{ Dietary data (energy-adjusted) } \\
\hline PRAL (mEq/day) & 15,46 & 17,22 & 12,92 & 16,53 & 17,72 & 17,67 & $0,564^{\mathfrak{f}}$ \\
\hline Proteins $(g)$ & 64,17 & 22,38 & 63,19 & 17,86 & 65,03 & 25,87 & $0,688^{:}$ \\
\hline Proteins $/ \mathrm{kg}$ of weight $(\mathrm{g} / \mathrm{Kg})$ & 1,07 & 0,46 & 0,92 & 0,29 & 1,20 & 0,55 & $0,009^{f}$ \\
\hline Phosphorus (mg) & 782,79 & 286,11 & 753,93 & 210,77 & 808,33 & 339,23 & $0,350^{*}$ \\
\hline Potassium (mg) & 1735,86 & 595,47 & 1790,56 & 669,96 & 1687,48 & 522,75 & $0,654^{\mathfrak{f}}$ \\
\hline Calcium (mg) & 382,59 & 225,91 & 362,35 & 219,50 & 400,50 & 232,08 & 0,407 \\
\hline Magnesium (mg) & 157,15 & 49,85 & 162,79 & 49,91 & 152,16 & 49,74 & $0,294^{\star}$ \\
\hline Animal protein $(\%)$ & 73,16 & 14,00 & 71,87 & 12,94 & 74,32 & 14,92 & $0,391^{*}$ \\
\hline Vegetable protein $(\%)$ & 26,40 & 13,72 & 28,07 & 12,95 & 24,94 & 14,34 & 0,262 \\
\hline Carbohydrates (g) & 189,15 & 35,97 & 192,10 & 32,16 & 186,55 & 39,15 & $0,449:$ \\
\hline Lipids (g) & 55,95 & 11,60 & 57,05 & 10,24 & 54,98 & 12,70 & $0,381 *$ \\
\hline Total calories (kcal) & 1648,36 & 739,75 & 1710,37 & 566,73 & 1593,51 & 866,53 & $0,438^{*}$ \\
\hline \multicolumn{8}{|l|}{ Clinical data } \\
\hline Urea $(\mathrm{mg} / \mathrm{dL})$ & 107,66 & 32,75 & 110,51 & 35,36 & 105,14 & 30,39 & $0,421^{\ddagger}$ \\
\hline Creatinine (mg/dL) & 8,89 & 0,08 & 10,23 & 3,26 & 7,71 & 2,38 & $<0,001$ \\
\hline Potassium (mEq/L) & 5,20 & 0,70 & 5,17 & 0,69 & 5,22 & 0,71 & $0,751^{\ddagger}$ \\
\hline Albumin $(g / L)$ & 4,30 & 0,40 & 4,43 & 0,36 & 4,18 & 0,39 & $\mathbf{0 , 0 0 2}$ \\
\hline Alkaline reserve $(\mathrm{mEq} / \mathrm{L})$ & 20,36 & 3,36 & 20,43 & 3,22 & 20,30 & 3,51 & $0,847^{*}$ \\
\hline GFR (mL/min) & 6,79 & 3,44 & 6,40 & 2,96 & 7,11 & 3,81 & 0,330 \\
\hline Hemodialysis time (years) & 4,36 & 3,93 & 4,20 & 3,64 & 4,50 & 4,19 & 0,704 \\
\hline \multicolumn{8}{|l|}{ Nutritional evaluation } \\
\hline BMI $\left(\mathrm{kg} / \mathrm{m}^{2}\right)$ & 24,48 & 4,12 & 24,91 & 3,35 & 24,11 & 4,70 & $0,201^{\mathfrak{f}}$ \\
\hline $\mathrm{HGS}(\mathrm{Kg})$ & 22,18 & 10,38 & 29,64 & 9,92 & 15,58 & 4,86 & $<\mathbf{0 , 0 0 1}^{\text {£ }}$ \\
\hline
\end{tabular}

SD - Standard Deviation; PRAL - Potential Renal Acid Load; GFR - Glomerular Filtration Rate; BMI - Body Mass Index; HGS - Hand Grip Strength; ${ }^{\ddagger}$ - Test t of Student for independent samples; ${ }^{£}$ - Mann Whitney test; $p$ value $-\mathrm{p}<0,05$. Source: Authors.

When comparing the averages of dietary data, clinical data and nutritional evaluation between the terciles of PRAL distribution, the protein $(\mathrm{g})$, the protein $\mathrm{g} / \mathrm{kg}$ of weight $(\mathrm{g} / \mathrm{kg}), \%$ of animal and vegetable protein, the phosphorus (mg), the lipid $(\mathrm{g})$ and the carbohydrate $(\mathrm{g})$ presented difference among terciles $(\mathrm{p}<0,05)$ (Table 3$)$. After multiple comparisons, apart from the $\%$ of vegetal protein, higher averages were observed in tercile 3 when compared to tercile 1 , while the average $\%$ of vegetal protein decreased with the increase of the tercile (Figure 1). 
Table 3 - Comparison of dietary and clinical data and nutritional evaluation according to the tertiles of distribution of PRAL of patients committed with CKD in hemodialysis listed for transplant in a university hospital in the northeast of Brazil. (2019)

\begin{tabular}{|c|c|c|c|c|c|c|c|c|c|}
\hline \multirow{3}{*}{ Variables } & \multicolumn{9}{|c|}{ PRAL (mEq/day) } \\
\hline & \multicolumn{2}{|c|}{ Total } & \multicolumn{2}{|c|}{$\begin{array}{r}\text { Tercile } 1 \\
(\mathbf{T} 1 \leq \mathbf{8 , 5 9})\end{array}$} & \multicolumn{2}{|c|}{$\begin{array}{c}\text { Tercile } 2 \\
(8,60 \leq \mathrm{T} 2 \leq 19,16)\end{array}$} & \multicolumn{2}{|c|}{$\begin{array}{c}\text { Tercile } 3 \\
(T 3 \geq 19,17)\end{array}$} & \multirow[b]{2}{*}{$p$} \\
\hline & Average & SD & Average & SD & Average & SD & Average & SD & \\
\hline \multicolumn{10}{|c|}{ Dietary data (energy-adjusted) } \\
\hline Protein $(g)$ & 64,17 & 22,38 & 50,91 & 10,61 & 58,80 & 13,13 & 82,63 & 26,02 & $<0,001$ \\
\hline Protein/kg of weight $(\mathrm{g} / \mathrm{Kg})$ & 1,07 & 0,46 & 0,85 & 0,25 & 0,99 & 0,32 & 1,38 & 0,58 & $<0, \mathbf{0 0 1}^{\mathfrak{f}}$ \\
\hline Phosphorus (mg) & 782,79 & 286,11 & 665,49 & 192,81 & 725,38 & 243,01 & 955,77 & 324,68 & $<0,001$ \\
\hline Potassium (mg) & 1735,86 & 595,47 & 1927,52 & 711,40 & 1629,24 & 525,54 & 1647,61 & 493,86 & $0,255^{\mathfrak{1}}$ \\
\hline Calcium (mg) & 382,59 & 225,91 & 374,64 & 212,56 & 389,21 & 224,56 & 384,13 & 246,09 & $0,966^{\ddagger}$ \\
\hline Magnesium (mg) & 157,15 & 49,85 & 170,27 & 50,70 & 150,36 & 45,64 & 150,62 & 51,73 & $0,179 *$ \\
\hline Animal protein $(\%)$ & 73,16 & 14,00 & 68,55 & 14,90 & 69,70 & 13,44 & 81,13 & 9,91 & $<0,001$ \\
\hline Vegetable protein $(\%)$ & 26,40 & 13,72 & 31,48 & 14,87 & 30,24 & 13,45 & 17,61 & 7,30 & $<0,001^{£}$ \\
\hline Carbohydrate (g) & 189,15 & 35,97 & 204,89 & 35,08 & 195,20 & 23,91 & 167,56 & 36,94 & $<0,001$ \\
\hline Lipid (g) & 55,95 & 11,60 & 50,65 & 11,14 & 55,41 & 8,63 & 61,79 & 12,12 & $<0,001$ \\
\hline Total calories (kcal) & 1648,36 & 739,75 & 1651,62 & 938,76 & 1614,69 & 611,98 & 1677,75 & 642,37 & $0,943^{*}$ \\
\hline \multicolumn{10}{|l|}{ Clinical data } \\
\hline Urea $(\mathrm{mg} / \mathrm{dL})$ & 107,66 & 32,75 & 111,01 & 33,01 & 106,36 & 37,39 & 105,57 & 28,11 & $0,783^{\ddagger}$ \\
\hline Creatinine (mg/dL) & 8,89 & 3,08 & 8,61 & 3,50 & 9,06 & 3,12 & 8,99 & 2,64 & 0,829 \\
\hline Potassium (mEq/L) & 5,20 & 0,70 & 5,22 & 0,73 & 5,23 & 0,71 & 5,13 & 0,68 & $0,848^{\ddagger}$ \\
\hline Albumin $(\mathrm{g} / \mathrm{L})$ & 4,30 & 0,40 & 4,17 & 0,43 & 4,39 & 0,38 & 4,33 & 0,35 & 0,072 \\
\hline Alkaline reserve (mEq/L) & 20,36 & 3,36 & 20,23 & 3,07 & 20,90 & 3,14 & 19,96 & 3,85 & $0,497 *$ \\
\hline GFR (mL/min) & 6,79 & 3,44 & 7,48 & 3,69 & 6,17 & 2,37 & 6,68 & 3,98 & 0,279 \\
\hline Hemodialysis (years) & 4,36 & 3,93 & 4,97 & 5,07 & 3,87 & 3,39 & 4,21 & 3,03 & 0,502 \\
\hline \multicolumn{10}{|l|}{ Nutritional evaluation } \\
\hline BMI $\left(\mathrm{kg} / \mathrm{m}^{2}\right)$ & 24,48 & 4,12 & 24,02 & 2,99 & 24,98 & 5,02 & 24,46 & 4,18 & $0,621^{*}$ \\
\hline $\operatorname{HGS}(\mathrm{Kg})$ & 22,18 & 10,38 & 22,52 & 9,54 & 23,90 & 11,13 & 20,17 & 10,41 & $0,536^{£}$ \\
\hline
\end{tabular}

PRAL - Potential Renal Acid Load; SD - Standard deviation; GFR - Glomerular Filtration Rate; BMI - Body Mass Index; HGS - Hand Grip Strength; ${ }^{\ddagger}$ - ANOVA one-way test ${ }^{£}{ }^{£}$ Kruskal-Wallis; $\mathrm{p}$ value $-\mathrm{p}<0,05$. Source: Authors. 
Figure 1 - PRAL - Potential Renal Acid Load ; T1 - Tercil 1 (T1 $\leq 8,59)$; T2 - Tercil 2 (8,60 $\leq \mathrm{T} 2 \leq 19,16)$; $\mathrm{T} 3$ - Tercil 3 (T3 $\geq$ 19,17); ANOVA one-way with Tukey post-test or Kruskal-Wallis Dunn post-test; ${ }^{*} \mathrm{p}<0,05 ;{ }^{* *} \mathrm{p}<0,001$.

(A)

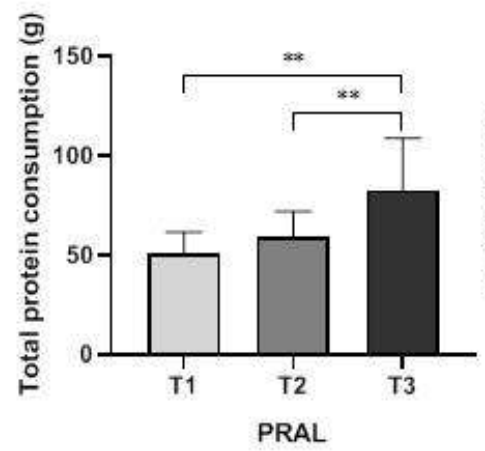

(D)

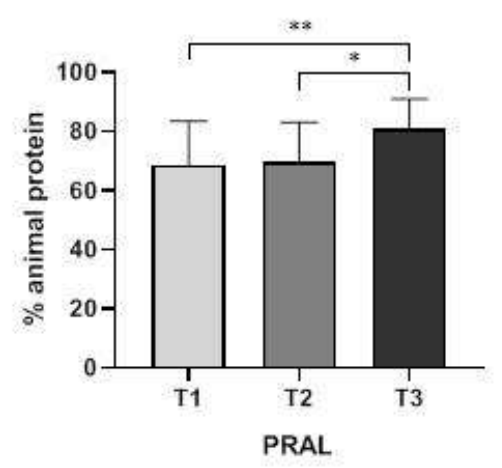

(F)

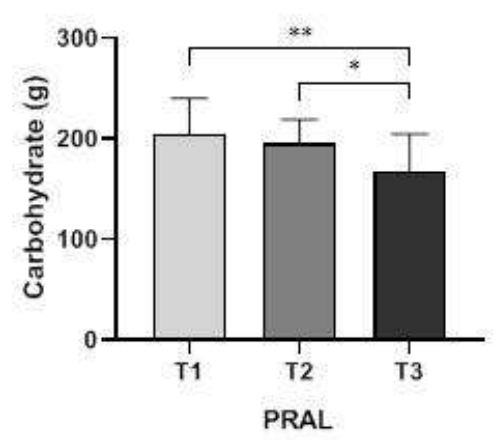

(C)

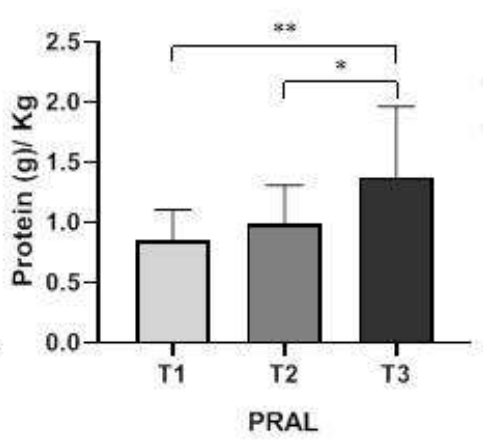

(E)

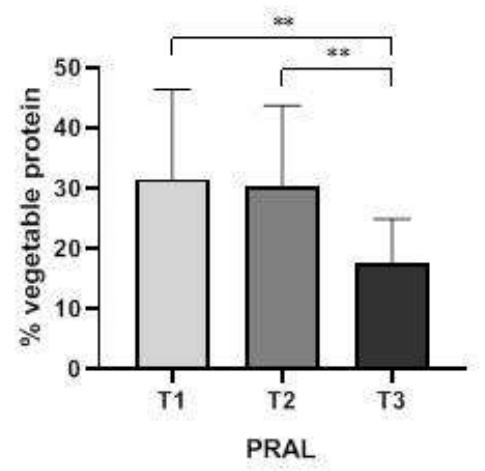

$(\mathrm{G})$

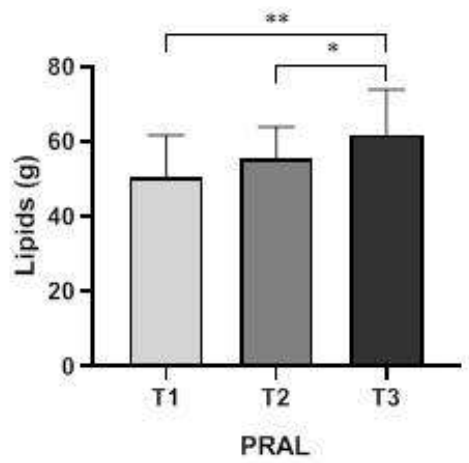

Source: Authors.

In the analysis of multinomial logistical regression, the greatest consumption of protein $(\mathrm{g})$, protein $/ \mathrm{kg}$ of weight $(\mathrm{g} / \mathrm{kg}), \%$ of animal protein, \% of vegetal protein, carbohydrate $(\mathrm{g})$ and lipid $(\mathrm{g})$ were associated with tercile 3 of PRAL distribution in relation to tercile 1 . It is possible to observe, in the adjustment model, that the greatest consumption of vegetal protein (\%) (OR: 0,87 RI95\%: 0,88 - 0,93) and carbohydrate (g) (OR: 0,96 RI95\%: 0,94-0,98) were protective factors for a less acidic diet. The increase of protein intake $(\mathrm{g})$ and the decrease of albumin $(\mathrm{g} / \mathrm{L})$ were associated to tercile 2 in comparison to tercile 1, regardless of gender, age, time of diagnosis and time of hemodialysis (Table 4). 


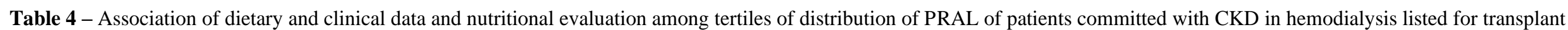
in a university hospital in the northeast of Brazil. (2019)

PRAL

\begin{tabular}{|c|c|c|c|c|c|c|c|c|c|c|}
\hline \multirow{4}{*}{ Variables } & \multicolumn{10}{|c|}{ PRAL } \\
\hline & \multicolumn{5}{|c|}{ Non-adjusted } & \multicolumn{5}{|c|}{ Adjusted } \\
\hline & Tertile & Tertile 2 & $p$ & Tertile 3 & $p$ & Tertile 1 & Tertile 2 & $p$ & Tertile 3 & $p$ \\
\hline & & OR (RI95\%) & & OR (RI95\%) & & & OR (RI95\%) & & OR (RI95\%) & \\
\hline \multicolumn{11}{|c|}{ Dietary data (energy-adjusted) } \\
\hline Protein (g) & Ref. & $1,04(1,01-1,07)$ & 0,020 & $1,10(1,08-1,20)$ & $<0,001$ & Ref. & $1,05(1,01-1,10)$ & 0,021 & $1,15(1,08-1,22)$ & $<0,001$ \\
\hline Protein $/ \mathrm{kg}$ of weight $(\mathrm{g} / \mathrm{kg})$ & Ref. & $1,05(1,01-1,10)$ & 0,060 & $1,14(1,08-1,20)$ & $<0,001$ & Ref. & $5,29(0,78-35,79)$ & 0,087 & $75,63(8,47-675,07)$ & $<0,001$ \\
\hline Phosphorus (mg) & Ref. & $1,00(0,99-1,00)$ & 1,001 & $1,01(1,01-1,02)$ & $<0,001$ & Ref. & $1,01(1,00-1,02)$ & 0,261 & $1,02(1,01-1,04)$ & $<0,001$ \\
\hline Potassium (mg) & Ref. & $1,00(0,99-1,01)$ & 0,060 & $1,00(1,00-1,01)$ & 0,074 & Ref. & $1,00(1,00-1,02)$ & 0,052 & $1,00(1,00-1,02)$ & 0,064 \\
\hline Calcium (mg) & Ref. & $1,00(0,99-1,01)$ & 0,794 & $1,00(0,99-1,01)$ & 0,862 & Ref. & $1,00(0,99-1,00)$ & 0,761 & $1,01(1,00-1,02)$ & 0,782 \\
\hline Magnesium (mg) & Ref. & $0,99(0,98-1,00)$ & 0,119 & $1,00(0,99-1,01)$ & 0,121 & Ref. & $1,00(0,98-1,00)$ & 0,118 & $0,99(0,98-1,00)$ & 0,115 \\
\hline Animal protein $(\%)$ & Ref. & $1,01(0,98-1,04)$ & 0,746 & $1,04(1,04-1,16)$ & $<0,001$ & Ref. & $1,01(0,97-1,04)$ & 0,691 & $1,10(1,04-1,16)$ & $<0,001$ \\
\hline Vegetable protein $(\%)$ & Ref. & $0,99(0,96-1,02)$ & 0,718 & $0,91(0,86-0,96)$ & $<0,001$ & Ref. & $0,99(0,96-1,03)$ & 0,697 & $0,87(0,88-0,93)$ & $<0,001$ \\
\hline Carbohydrate (g) & Ref. & $0,98(0,97-1,00)$ & 0,186 & $0,96(0,95-0,98)$ & $<0,001$ & Ref. & $0,98(0,97-1,00)$ & 0,161 & $0,96(0,94-0,98)$ & $<0,001$ \\
\hline Lipid (g) & Ref. & $1,04(0,99-1,09)$ & 0,079 & $1,10(1,04-1,10)$ & $<0,001$ & Ref. & $1,06(1,00-1,12)$ & $\mathbf{0 , 0 3 3}$ & $1,13(1,06-1,20)$ & $<0,001$ \\
\hline \multicolumn{11}{|l|}{ Clinical data } \\
\hline Urea (mg/dL) & Ref. & $0,99(0,98-1,01)$ & 0,613 & $0,99(0,98-1,01)$ & 0,503 & Ref. & $0,99(0,97-1,00)$ & 0,401 & $0,99(0,97-1,00)$ & 0,321 \\
\hline Creatinine (mg/dL) & Ref. & $1,05(0,89-1,23)$ & 0,554 & $1,04(0,88-1,22)$ & 0,615 & Ref. & $1,08(0,98-1,30)$ & 0,431 & $1,04(0,86-1,25)$ & 0,687 \\
\hline Potassium (mEq/L) & Ref. & $1,01(0,50-2,03)$ & 0,976 & $0,83(0,41-1,66)$ & 0,598 & Ref. & $0,99(0,47-2,08)$ & 0,988 & $0,83(0,39-1,75)$ & 0,632 \\
\hline Albumin $(g / L)$ & Ref. & $4,40(1,11-17,51)$ & $\mathbf{0 , 0 3 5}$ & $2,68(0,73-9,83)$ & 0,137 & Ref. & $5,38(1,10-26,28)$ & $\mathbf{0 , 0 3 7}$ & $2,74(0,63-11,97)$ & 0,179 \\
\hline Alkaline reserve (mEq/L) & Ref. & $1,06(0,91-1,23)$ & 0,418 & $0,98(0,84-1,13)$ & 0,739 & Ref. & $1,08(0,93-1,27)$ & 0,305 & $1,00(0,86-1,16)$ & 0,998 \\
\hline GFR (mL/min) & Ref. & $0,89(0,76-1,03)$ & 0,141 & $0,94(0,82-1,07)$ & 0,375 & Ref. & $0,87(0,74-1,02)$ & 0,090 & $0,93(0,93-1,07)$ & 0,308 \\
\hline
\end{tabular}


Research, Society and Development, v. 10, n. 6, e12910615590, 2021

(CC BY 4.0) | ISSN 2525-3409 | DOI: http://dx.doi.org/10.33448/rsd-v10i6.15590

\begin{tabular}{|c|c|c|c|c|c|c|c|c|c|c|}
\hline BMI $\left(\mathrm{kg} / \mathrm{m}^{2}\right)$ & Ref. & $1,05(0,94-1,19)$ & 0,350 & $1,05(0,94-1,19)$ & 0,659 & Ref. & $1,07(0,94-1,22)$ & 0,271 & $1,04(0,92-1,19)$ & 0,477 \\
\hline HGS (Kg) & Ref. & $1,01(0,97-1,06)$ & 0,603 & $0,97(0,92-1,02)$ & 0,917 & Ref. & $1,03(0,96-1,11)$ & 0,343 & $0,95(0,86-1,02)$ & 0,177 \\
\hline
\end{tabular}

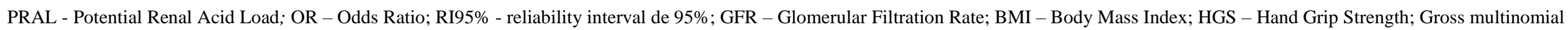
logistical regression and adjusted by gender, age, time of diagnosis and time of hemodialysis; $p$ value $-\mathrm{p}<0,05$. Source: Authors. 


\section{Discussion}

In this study, we can see that more acidic diets, evaluated by PRAL, are associated with higher protein consumption, with a difference between types (animal and vegetable), where the highest vegetable protein consumption was a protective factor. Although this algorithm does not specify the source of protein, because it does not distinguish the sulfured amino acids, that are abundant in the proteins of animal source (Mafra et al., 2018). Another finding was that low carbohydrate consumption was related to the highest PRAL tercile. It was not possible to observe association between PRAL and the nutritional status of these patients.

It is well stablished in the literature that a high protein intake may harm renal function in a CKD scenario, what has been studied in the past years is what is the source of protein that may in fact develop and promote the deterioration of renal function (Rodrigues Neto Angéloco et al., 2018). The last studies show that the reduced consumption of fruits and vegetables increases endogenous formation of acids and may intensify the worsening of disease-related complications in these patients (Toba et al., 2019). This is due to the fact that the majority of amino acids coming from greenery, fruits and legumes when metabolized produce alkali that neutralize the acids, for these foods contain organic acids, such as citric acids, and organic salts, such as potassium citrate (Passey, 2017).

The average of PRAL in the diet of patients in hemodialysis listed for renal transplant was of $15,46 \mathrm{mEq} / \mathrm{day}$. In other studies, conducted in different countries a lower average is observed (Halil et al., 2016, Vezzoli et al., 2015, Mirmiran et al., 2016). When comparing the population of origin to the average of PRAL, it was superior to the consumption of the ordinary diet of the northeastern Brazilian population (11,7 mEq/day) (Carnauba et al., 2015). Considering the nutritional transition, it is verified that the composition of Brazilian diet has an important acidic potential, given the elevated consumption of protein. An unbalance is observed between protein sources, in which there is an increase of animal protein at the expense of vegetal protein (Carnauba et al., 2015).

Regarding the association between PRAL and carbohydrate intake, other studies have observed a difference between carbohydrate consumption and PRAL terciles, in which lower consumption was observed in the highest tercile in another population (Xu et al., 2014, Moghadam et al., 2016, López et al., 2020). Iwase et al. (2015) found that in patients diagnosed with type 2 diabetes, there is a positive correlation between the consumption of carbohydrates and fibers with vegetal protein. These patients with higher consumption of vegetable proteins and with a lower PRAL score are less likely to develop metabolic syndrome.

This association observed in this study may result from the quality of carbohydrates. High fiber consumption is related to several benefits in the control of chronic non-communicable diseases (Reynolds et al., 2019). In renal patients, adequate fiber consumption helps to modulate the intestinal microbiota and the acid-base balance (Cupisti et al., 2017).

Being the proteins of animal source one of the contributions of phosphorus in the diet (Noori et al., 2010, KalantarZadeh et al., 2010), we observed that a more acidic diet was related to a greater amount of phosphorus when comparing the averages among terciles, which was also observed by Garcia-Torres et al. (2020). The elevated consumption of lipids was also associated with diets with a greater presence of acids (tercile 3). This is probably due to the elevated consumption of animal proteins which are also a source of fats (Mafra et al., 2018).

Another important finding was the significant statistical difference among the creatinine, albumin and HGS between genders, being the superior averages noticed in men. The creatinine is a relevant marker of muscular mass preservation in individuals undergoing hemodialysis (Sakao et al., 2016, Antón-Pérez et al., 2018). Furthermore, the albumin is one of the markers for identification of undernourishment in these patients (Fouque et al., 2008) and the low HGS is an indicator for diagnosing sarcopenia (Cruz-Jentoft, 2019). Two other studies noticed that the serum creatinine combined with other markers 
of renal function is associated with lower muscular strength with CKD patients (Lin et al., 2019, Poppe et al., 2020). The women undergoing hemodialysis tend to have less muscular strength when comparing to men (Poppe et al., 2020), as observed in the general population, this is due to the renovation of muscular cells, content and proliferation of satellite cells, hormonal interactions and mitochondrial differences between women and men (Rosa-Caldwell \& Greene, 2019).

This study is the first to evaluate the acidic charge of the habitual diet of patients in substitutive renal therapy in waiting lists for transplant with a relevant sampling number. Another positive aspect of the research is the homogeneity of the studied population accounting for origin and feeding habits. However, some limitations must be pondered to improve the interpretation of the presented, such as the use of Rc24h and predictive formula to stimulate the acidic charge in the diets, besides that the team of recruitment was trained to apply the Rc24h and to analyze the variables of consumption that influence the estimative of acidic charge, with the intend of diminishing bias. Moreover, the sectional outlining of the study limits itself to affirm with certainty about the acidic charge of the diet and the impact in the renal disease and nutritional status of patients in hemodialysis who are in waiting list for transplant. Non-probabilistic sample of convenience does not allow to extrapolate the results aside from the population studied.

\section{Conclusion}

In synthesis, the PRAL showed association with protein consumption, being possible to observe a positive effect of the vegetal protein sources over the acidic charge in the diet. Just like vegetal protein, the carbohydrate showed a protective effect. In what the nutritional status is concerned, there was not association among PRAL, BMI and muscular strength, however it was possible to observe that the women in this population show fewer markers of mass and muscular strength than men.

Given the limitations of the study, the urgency, and the importance of the theme, it is relevant that researches are developed with adequate outlining for real inferences. Studies with a longitudinal design, as well as interventional studies, using acid-base status markers (urine $\mathrm{pH}$, serum bicarbonate, and Net Endogenous Acid production from urine) and evaluating food patterns can enrich the knowledge about the impact of the dietary acid load on the nutritional status and outcomes in kidney disease and post-transplantation of these patients.

Studies within this context may foment more assertive actions towards diet therapies, seeking balance between both animal and vegetable protein sources, avoiding excessive feeding restrictions in terms of vegetal food sources, with the intent of diminishing metabolic acidosis, preserving muscular mass, lowering the impact of the disease in the quality of life and in the nutritional status of these patients, besides promoting healthier feeding habits that are essential for the maintenance of good health after a renal transplant.

\section{References}

Akchurin, O. M. \& Kaskel, F. (2015). Update on inflammation in chronic kidney disease. Blood Purif., 39(1-3), 84-92.

Antón-Pérez, G., Santana-Del-Pino, A., Henríquez-Palop, F., Monzón, T., Sánchez, A. Y., Valga, F., et.al. (2018). Diagnostic Usefulness of the Protein Energy Wasting Score in Prevalent Hemodialysis Patients. J Ren Nutr., 28(6), 428-434.

Brasil. (2011). Orientações para a coleta e análise de dados antropométricos em serviços de saúde: Norma Técnica do Sistema de Vigilância Alimentar e Nutricional-SISVAN.

Chung, H., Lam, V. W., Yuen, L. P., Ryan, B. J., O'Connell, P. J., Chapman, J. R., et.al. (2015). Renal transplantation: better fat than thin. J Surg Res., 194(2), 644-652.

Carnauba, R. A., Sussaio, M. M., Fonseca, A. B. B. L. \& Naves, A. (2015). Avaliação do potencial acidificante da dieta típica brasileira. Rev Bras Nutr Clin., 30(4), 309-316. 
Cruz-Jentoft, A. J., Bahat, G., Bauer, J., Boirie, Y., Bruyère, O., Cederholm, T., et.al. (2019). Sarcopenia: revised European consensus on definition and diagnosis. Age Ageing, 48(4), 16-31.

Cupisti, A., D'Alessandro, C., Gesualdo, L., Cosola, C., Gallieni, M., Egidi, M. F., et.al. (2017). Non-Traditional Aspects of Renal Diets: Focus on Fiber, Alkali and Vitamin K1 Intake. Nutrients, 9(5), 444-458.

Fess, E. E. Grip strength. (1992). In Casanova, J. S. (Ed.). Clinical assessment recommendations. (2a ed.) American Society of Hand Therapists.

Fouque, D., Kalantar-Zadeh, K., Kopple, J., Cano, N., Chauveau, P., Cuppari, L., et.al. (2008). A proposed nomenclature and diagnostic criteria for proteinenergy wasting in acute and chronic kidney disease. Kidney Int., 73(4), 391-398.

Garcia-Torres, R., Young, L., Murray, D. P., Kheda, M. \& Nahman, N. S. (2020). Dietary Protein Source and Phosphate Levels in Patients on Hemodialysis. J Ren Nutr., S1051-2276(19), 30428-30425.

Goraya, N. \& Wesson, D. E. (2017). Management of the Metabolic Acidosis of Chronic Kidney Disease. Adv Chronic Kidney Dis., 24(5), 298-304.

Halil, O. I., Leila, Z., John, R., Laura, C., Kristina, M.U., Bryan, K., et.al. (2016). Dietary Acid Load Is Associated with Serum Bicarbonate but Not Insulin Sensitivity in Chronic Kidney Disease. J Ren Nutr., 26(2), 93-102.

Harambat, J., Kunzmann, K., Azukaitis, K., Bayazit, A. K., Canpolat, N., Doyon, A., et.al. (2017). Metabolic acidosis is common and associates with disease progression in children with chronic kidney disease. Kidney Int., 92(6),1507-1514.

Iwase, H., Tanaka, M., Kobayashi, Y., Wada, S., Kuwahata, M., Kido, Y., et.al. (2015). Lower vegetable protein intake and higher dietary acid load associated with lower carbohydrate intake are risk factors for metabolic syndrome in patients with type 2 diabetes: Post-hoc analysis of a cross-sectional study. $J$ Diabetes Investig., 6(4), 465-472.

Kalantar-Zadeh, K., Gutekunst, L., Mehrotra, R., Kovesdy, C. P., Bross, R. \& Shinaberger, C. S. (2010). Understanding Sources of Dietary Phosphorus in the Treatment of Patients With Chronic Kidney Disease. Clin J Am Soc Nephrol., 5(3), 519-530.

Lin, Y. L., Chen, S. Y., Lai, Y. H., Wang, C. H., Kuo, C. H., Liou, H. H., et.al. (2019). Serum Creatinine to Cystatin C Ratio Predicts Skeletal Muscle Mass and Strength in Patients with Non-Dialysis Chronic Kidney Disease. Clin Nutr., S0261-5614(19), 33119-X.

López, M., Moreno, G., Lugo, G. \& Marcano, G. (2020). Dietary acid load in children with chronic kidney disease. Eur J Clin Nutr., 74(Suppl 1), 57-62.

Mafra, D., Borges, N. A., Cardozo, L. F. M. F., Anjos, J. S., Black, A. P., Moraes, C., et.al. (2018). Red meat intake in chronic kidney disease patients: Two sides of the coin. Nutrition, 46, 26-32.

Ministério da Saúde (BR), \& Conselho Nacional de Saúde. (2012). Resolução $\mathrm{n}^{\circ} 466$ de 12 de dezembro de 2012. Aprova diretrizes e normas regulamentadoras de pesquisas envolvendo seres humanos. Diário Oficial da União [da] República Federativa do Brasil, 150(112). Recuperado de: http://www.conselho.saude.gov.br/web_comissoes/conep/index.html.

Mirmiran, P., Yuzbashian, E., Bahadoran, Z., Asghari, G. \& Azizi, F. (2016). Dietary Acid-Base Load and Risk of Chronic Kidney Disease in Adults: Tehran Lipid and Glucose Study. Iran J Kidney Dis., 10(3), 119-125.

Moghadam, S. K., Bahadoran, Z., Mirmiran, P., Tohidi, M. \& Azizi, F. (2016). Association between Dietary Acid Load and Insulin Resistance: Tehran Lipid and Glucose Study. Prev Nutr Food Sci., 21(2), 104-109.

Noori, N., Sims, J. J., Kopple, J. D., Shah, A., Colman, S., Shinaberger, C. S., et.al. (2010). Organic and Inorganic Dietary Phosphorus and Its Management in Chronic Kidney Disease. Iran J Kidney Dis., 4(2), 89-100.

Osuna-Padilla, I. A., Leal-Escobar, G., Garza-García, C. A. \& Rodríguez-Castellanos, F. E. (2019). Dietary Acid Load: Mechanisms and evidence of its health repercussions. Nefrología, 39(4), 343-354

Passey, C. (2017). Reducing the Dietary Acid Load: How a More Alkaline Diet Benefits Patients with Chronic Kidney Disease. J Ren Nutr., 27(3), 151-160.

Poppe, E. S. J. M., Polinder-Bos, H. A., Huberts, M., Vogels, S., Ipema, K. J. R., Gansevoort, R. T., et.al. (2020). Creatinine Synthesis Rate and Muscle Strength and Self-Reported Physical Health in Dialysis Patients. Clin Nutr., 39(5), 1600-1607.

Raphael, K. L. (2019). Metabolic Acidosis in CKD: Core Curriculum 2019. Am J Kidney Dis., 74(2), 263-275.

Remer, T. \& Manz, F. (1995). Potential renal acid load of foods and its influence on urine pH. J Am Diet Assoc., 95(7), 791-797.

Reynolds, A., Mann, J., Cummings, J., Winter, N., Mete, E. \& Te Morenga, L. (2019). Carbohydrate quality and human health: a series of systematic reviews and meta-analyses. Lancet, 393(10170), 434-445.

Rodrigues Neto Angéloco, L., Arces de Souza, G. C., Almeida Romão, E. \& Garcia Chiarello, P. (2018). Alkaline Diet and Metabolic Acidosis: Practical Approaches to the Nutritional Management of Chronic Kidney Disease. J Ren Nutr., 28(3), 215-220.

Rosa-Caldwell, M. E. \& Greene, N. P. (2019). Muscle metabolism and atrophy: let's talk about sex. Biol Sex Differ., 10(1), 1-14.

Sajgure, A. D., Dighe, T. A., Korpe, J. S., Bale, C. B., Sharma, A. O., Shinde, N. S., et.al. (2017). The Relationship between Metabolic Acidosis and Nutritional Parameters in Patients on Hemodialysis. Indian J Nephrol, 27, 190-194.

Sakao, Y., Ojima, T., Yasuda, H., Hashimoto, S., Hasegawa, T., Iseki, K., et.al. (2016). Serum Creatinine Modifies Associations Between Body Mass Index and Mortality and Morbidity in Prevalent Hemodialysis Patients. PLoS One, 11(3), e0150003. 
Research, Society and Development, v. 10, n. 6, e12910615590, 2021

(CC BY 4.0) | ISSN 2525-3409 | DOI: http://dx.doi.org/10.33448/rsd-v10i6.15590

Stevens, L. A., Schmid, C. H., Zhang, Y. L., Coresh, J., Manzi, J., Landis, R., et.al. (2010). Development and validation of GFR-estimating equations using diabetes, transplant and weight. Nephrol Dial Transplant., 25(2), 449-457.

Toba, K., Hosojima, M., Kabasawa, H., Kuwahara, S., Murayama, T., Yamamoto-Kabasawa, K., et.al. (2019). Higher estimated net endogenous acid production with lower intake of fruits and vegetables based on a dietary survey is associated with the progression of chronic kidney disease. BMC Nephrol., 20(1), 1-11

Vezzoli, G., Dogliotti, E., Terranegra, A., Arcidiacono, T., Macrina, L., Tavecchia, M., et.al. (2015). Dietary Style and Acid Load in an Italian Population of Calcium Kidney Stone Formers. Nutr Metab Cardiovasc Dis., 25(6), 588-593

Webster, A. C., Nagler E. V., Morton, R. L. \& Masson, P. (2017). Chronic Kidney Disease. Lancet, 389, 1238-1252.

Willett, W.C., Howe, G. R. \& Kushi, L. H. (1997). Adjustment for total energy intake in epidemiologic studies. The American journal of clinical nutrition, $65(4), 1220 \mathrm{~S}-1228 \mathrm{~S}$.

World Health Organization. (2010). Global recommendations on physical activity for health.

World Health Organization. (1997). Obesity. Preventing and managing the global epidemic. Geneva: report of a WHO consultation on obesity.

Xu, H., Jia, T., Huang, X., Risérus, U., Cederholm, T., Arnlöv, J., et.al. (2014). Dietary acid load, insulin sensitivity and risk of type 2 diabetes in communitydwelling older men. Diabetologia, 57(8), 1561-1568. 